SYMBOLAE PHILOLOGORUM POSNANIENSIUM GRAECAE ET LATINAE XXIV/1 • 2014

pp. 85-93. ISBN 978-83-7654-279-9. ISSN 0302-7384

DOI: 10.14746/SPPGL.2014.XXIV.1.6

\title{
ALEKSANDRA ARNDT
}

Instytut Filologii Klasycznej Uniwersytetu im. Adama Mickiewicza

ul. Fredry 10, 61-701 Poznań

Polska - Poland

\section{Z TIBULLUSOWEJ PALETY GATUNKOWEJ. MODLITWA I HYMN JAKO WYKŁADNIKI PROGRAMU POETYCKIEGO ELEGIKA}

\begin{abstract}
Arndt Aleksandra, Z Tibullusowej palety gatunkowej. Modlitwa i hymn jako wykładniki programu poetyckiego elegika (Analysis of hymns and prayers in the love elegies of Tibullus).

The author's aim is to analyse religious hymns and litterary prayers contained in love elegies by Tibullus. These genres are used in order to emphasise his sincere relation with poet's native villages and to underline his intense attachment to Messala.
\end{abstract}

Keywords: Tibullus, love elegy, prayer, religious hymn.

Tibullus, podobnie jak dwaj pozostali elegicy rzymscy, chętnie sięgał w swojej twórczości po hymn, a także pokrewną mu modlitwę ${ }^{1}$. Gatunki te, o greckiej proweniencji, stanowiły wszak dogodną formę wyrażania emocji właściwych dla erotyczno-patriotycznego profilu elegii w Rzymie; w ich ramach nietrudno było wystosować prośbę do bogów o wzajemność w uczuciu czy też wyrazić podziw dla panującego władcy. Takimi właśnie treściami nasycali hymn i modlitwę Propercjusz (np. III 17) oraz Owidiusz (np. Am. III 2). Tibullus, w którego poezji dominantę tematyczną obok wątków miłosnych stanowiły zagadnienia wiejskie, wykorzystywał hymn i modlitwę także dla uwypuklenia doniosłości problematyki rustykalnej w swoich pieśniach.

$\mathrm{Z}$ przejawem podobnego zastosowania drugiego z wymienionych gatunków spotykamy się już w programowej elegii księgi pierwszej. W strukturze tej pieśni zamknął poeta modlitw ę do bogów wiejskich - Cerery, Priapa i Larów (I 1, 15-24).

Prekacje w obręb innych, większych utworów włączali powszechnie już poeci greccy. Te wypowiedzi religijne o wyraźnie lirycznym charakterze stawały się

${ }^{1}$ M. Swoboda, J. Danielewicz, Modlitwa i hymn w poezji rzymskiej, Poznań 1981, s. 15, przypominają, że w opinii religioznawców hymn stanowi pochodną modlitwy. 
częścią dzieł epickich, dramatycznych, a także rozbudowanych form poetyckich; mogły również funkcjonować samodzielnie, czego najlepszym bodajże przykładem jest słynna pieśń błagalna Safony do Afrodyty (fr. 1 E. - M. Voigt). Budowa modlitw literackich (ukształtowanych w czasach Homera) była jasna i klarowna. Nawet w zminiaturyzowanej postaci musiały one zawierać dwa elementy: imię adresata $\mathrm{w}$ wołaczu, tudzież prośbę w formie rozkazu. W rozbudowanych utworach tego gatunku badacze wydzielili natomiast trzy części: wezwanie (in. inwokację określenie adresata przy użyciu epitetów mających za zadanie zjednać jego życzliwość), sankcję (in. hypomnezę - przypomnienie okoliczności zobowiązujących bóstwo do spełnienia błagania) oraz prośbę (wyartykułowanie życzenia)².

Tibullus inkorporował w elegię I 1 modlitwę o takiej właśnie trójczłonowej budowie. Usytuowana tuż za pierwszą częścią wykładu na temat własnej orientacji światopoglądowej poety, potwierdza niejako i przypieczętowuje dokonany przez niego wybór niekonwencjonalnej drogi życiowej. Ponadto, dzięki wprowadzeniu modlitwy, demonstruje twórca swą dbałość o wysoką jakość obranej formy egzystencji.

Prekacja zainaugurowana zostaje bezpośrednim zwrotem do Cerery (ww. 15-16). Obdarzywszy boginię epitetem flava 'płowa, jasnowłosa', poeta przekazuje jej w darze koronę z kłosów zbóż ${ }^{4}$ ma ona zostać umieszczona na wrotach świątyni rzymskiej Demeter. Ofiara funkcjonuje w utworze jednocześnie na zasadzie prośby do Cerery o urodzaj, gdyż, jak trafnie zauważają w swojej książce Modlitwa i hymn w poezji rzymskiej Michał Swoboda i Jerzy Danielewicz, „warunkiem spełnienia wotów jest... uprzednie uzyskanie plonów"5. W dwóch kolejnych wersach koncentruje poeta swą uwagę wokół Priapa (ww. 17-18). Określenie boskiego adresata mianem ruber 'cynobrowy' stanowi aluzję do roli, jaką odgrywały w rzymskich sadach drewniane wyobrażenia tego bożka: pomalowane na czerwono i z sierpem w dłoni odstraszały złodziei i ptaki. Poeta wyraża nadzieję, że podobizna Priapa spełni to zadanie także na terenie jego posiadłości; wotum stanowi tu umiejscowienie posągu opiekuna fauny w ogrodzie twórcy. Przed ostatnim z adresatów, Larami, nie wyłuszcza poeta konkretnej prośby, słusznie zakładając, iż jej treść wynika z epitetu, jakim obdarzył bóstwa: agri custodes 'strażnicy pól'. Celem wyegzekwowania u Larów straży nad gruntami poeta przypomina o płodach rolnych, jakie sam składa im w ofierze (ww. 19-20). Przywoływani już Swoboda i Danielewicz wskazują słusznie, że ,zdanie »wy także otrzymujecie należne wam dary« nakazuje

${ }^{2}$ Definicja modlitwy za: M. Swoboda, J. Danielewicz, op. cit., s. 9-15 i J. Danielewicz, Liryka starożytnej Grecji, Warszawa-Poznań 2001, s. 68.

${ }^{3} \mathrm{~W}$ ten sposób boginię charakteryzują również Verg. Georg. I 96 oraz Ov. Am. III 10, 3 i Fast. IV 424.

${ }^{4} \mathrm{Na}$ wieniec zbożowy jako symbol władzy i atrybut Cerery wskazują M. Swoboda, J. Danielewicz, op. cit., s. 67.

${ }^{5}$ Ibidem, s. 67. 
rozciągnąc hypomnezę, w tym miejscu dopiero - z formalnego punktu widzenia - zaczętą, także na dwa wcześniejsze człony modlitwy"'. Tibullus kontynuuje następnie partię sankcyjno-wotywną $\mathrm{w}$ dwóch kolejnych wersach, napomykając przy okazji o zubożeniu własnego majątku (ww. 21-22). Modlitwę zamyka dystychem, w którym zawiera okrzyk rytualny, jaki towarzyszyć ma młodzieży przy składaniu odbiorcom prekacji ofiary z owcy (ww. 23-24).

W twórczości Tibullusa bogowie wiejscy cieszyli się niezwykle wysoką rangą. Modlitwa z prośbą o pieczę nad gospodarstwem stanowiła z pewnością szczególny przejaw przywiązania poety do „niebieskich rolników” (agricolae caelites, II 1,36) i żywionej względem nich estymy. Wyjątkową rolę, jaką powierzył twórca temu nośnikowi własnych uczuć religijnych, potwierdza usytuowanie prekacji na czele pierwszej księgi, w elegii programowej. Jednak z modlitwą do boskich patronów rolnictwa spotykamy się także w drugim zbiorze, wplecioną - podobnie jak poprzedniczka - w pieśń inauguracyjną. Inaczej niż w przypadku utworu I 1, dogodny pretekst do modłów podsunęły tu poecie okoliczności świąteczne - uroczystość Ambarwaliów.

Przy okazji kolejnej modlitwy do niebian (II 1, 17-24) poeta postawił czytelnikom pewną zagadkę: nie wyjawił im mianowicie tożsamości adresatów swej przemowy, uciekając się jedynie do ogólnikowego określenia di patrii 'bóstwa domowe', 'bóstwa ojców' (w. 17). Możemy jednak zidentyfikować je bez trudu. Zarówno sama tytulatura, jak i charakter święta wskazują, że odbiorcami modlitwy byli Cerera i Bachus. Wielce prawdopodobne wydaje się poza tym, iż zwrotem di pragnął poeta objąc także Lary ${ }^{7}$; tym prastarym strażnikom mienia i opiekunom posiadłości składał wszak ofiarę również w elegii programowej księgi pierwszej (I 1, 19-20) ${ }^{8}$.

Tożsamość adresatów determinuje ponadto treść następującej po inwokacji do bogów prośby - jest nią błaganie o odwrócenie od pól klęski nieurodzaju i zapobiegnięcie losowemu zmniejszaniu liczebności stada (ww. 17-20)9. Tuż za prośbą zamieszcza poeta rozbudowany człon hypomnezyjny (ww. 21-24) ${ }^{10}$ :

${ }^{6}$ Ibidem, s. 67.

${ }^{7}$ P. Pöstgens, Tibulls Ambarvalgedicht (II, 1), Würzburg-Aumühle 1940, s. 9, jest zdania, że pod określeniem di patrii kryją się ,allgemein die Götter, die von den Vorfahrern verehrt wurden”.

${ }^{8} \mathrm{D}$. Baudy, Römische Umgangsriten. Eine ethologische Untersuchung der Funktion von Wiederholung für religiöses Verhalten, Tübingen 1998, s. 127-147, wyraża przekonanie, iż ogólnikowy zwrot di pozwala na włączenie do listy boskich adresatów również Kupidyna. Nam nie wydaje się jednak, by istniały po temu odpowiednie przesłanki. Sądzimy raczej, iż w tej części utworu twórcy zależało jeszcze na nieprzywoływaniu boga miłości. Wszelkie wzmianki na temat Amora czy ewokacje skojarzeń z jego boską postacią mogłyby zniweczyć efekt zaskoczenia, jaki osiągnął poeta przez nieoczekiwane wskazanie w całkowicie, wydawałoby się, „,neutralnej” elegii na sioło jako miejsce narodzin rzymskiego Erosa.

${ }^{9}$ M. Swoboda, J. Danielewicz, op. cit., s. 65, podobną treścią wypełnione były również archaiczne prekacje apotropaiczne.

${ }^{10}$ P. Pöstgens, op. cit., s. 11, za koniec modlitwy uważa natomiast wers 20. 
celem zobligowania adresatów modlitwy do spełnienia życzeń roztacza wizję wiejskiego dobrobytu jako konsekwencji boskiej przychylności względem wieśniaków. Wśród rozlicznych przejawów spodziewanego dostatku wyróżnia m. in. ogień ofiarny rolnika w podzięce za obfite plony (... rusticus ... / ingeret ardenti grandia ligna foco, w. 21-2) oraz liczne potomstwo niewolników (turbaque vernarum, saturi bona signa coloni, w. 23). Obrazem pomyślnej przyszłości zamyka twórca całą, bez wątpienia zbiorową [formy: purgamus (w. 17) oraz nostris (w. 18)] modlitwę - kolejne wersy eksponują już rolę poety jako mistrza ceremonii.

W świątecznym utworze II 1 Tibullus jeszcze kilkakrotnie podejmuje wątki religijne. Za powtarzanymi regularnie zwrotami do niebieskich opiekunów rolnictwa kryją się nie tylko kolejne prośby $\mathrm{i}$ - jak zobaczymy dalej - skryte życzenia, ale przede wszystkim chęć przyzwania bogów na uroczystość Ambarwaliów. Jako formę apelu o przybycie niebian obiera elegik powstały z prekacji, uświęcony kilkusetletnią tradycją literacką hy m n klety c zn y.

Zdaniem Menandra, retora z III w. n.e., hymny kletyczne (przyzywające) występowały powszechnie w twórczości Safony i Alkmana ${ }^{11}$. Jerzy Danielewicz w następujący sposób scharakteryzował ich budowę w książce Liryka starożytnej Grecji:

[...] Hymny kletyczne zawierają prośby o przybycie kierowane pod adresem nieobecnego na uroczystości bóstwa. Wymienia się w nich miejsca znanego lub przypuszczalnego pobytu adresata, a także opisuje uroki miejsca, do którego ma on przybyć. Prośba może precyzować pewne szczegóły (pożądany sposób nadejścia, życzliwy nastrój). Typowym elementem wydaje się określenie celu przybycia bóstwa: jest nim, podobnie jak w modlitwie, spełnienie przedłożonych błagań ${ }^{12}$.

Pierwszy hymn kletyczny ${ }^{13}$ pieśni II 1 adresuje poeta do Bachusa i Cerery:

Bacche, veni, dulcisque tuis e cornibus uva pendeat, et spicis tempora cinge, Ceres! (II 1, 3-4)

Bachusie, przybądź! Z rogów twoich słodkie grona Niech zwisną! Otocz skronie kłosami, Cerero!*

W wezwaniu, które z uwagi na niewielkie rozmiary określić można mianem miniatury hymnu przyzywającego, artykułuje poeta swoje preferencje odnośnie do ekwipunku bóstw wzywanych na uroczystości. Życzeniem twórcy jest przystrojenie się boskiej pary w łatwo rozpoznawalne atrybuty: rzymski

\footnotetext{
* Wszystkie przekłady autorstwa autorki artykułu.

${ }^{11}$ Zob. M. Swoboda, J. Danielewicz, op. cit., s. 16.

${ }^{12}$ J. Danielewicz, Liryka starożytnej Grecji. Warszawa-Poznań 2001, s. 39.

${ }^{13}$ P. Pöstgens, op. cit., s. 2, zastanawia się również nad modlitewnym charakterem passusu.
} 
Dionizos zawiesić ma na rogach ${ }^{14}$ kiście winogron, zaś matka Proserpiny - włożyć na głowę wieniec z kłosów; przywiązanie do tradycyjnego wizerunku Cerery zdradzał Tibullus już wcześniej, w elegii I 1, 15-16 $6^{15}$.

Również drugi w układzie pieśni hymn kletyczny - ku chwale bogów wiejskich (II 1, 37-66) ${ }^{16}$ - zaprezentował poeta odbiorcom w formie mocno zredukowanej. Twórca zrezygnował tu z apelu do opiekunów agrokultury o przybycie na święto (ten dokonał się poniekąd już wcześniej, w ramach modlitwy) i przedstawił wyłącznie część laudacyjną - boskie zasługi dla rozwoju sztuki rolniczej, tudzież pochwałę sioła. Ciekawe obserwacje na temat utworu poczynili w ewokowanej już pozycji Modlitwa i hymn w poezji rzymskiej Swoboda i Danielewicz. Zdaniem uczonych, „niektóre urywki [sc. hymnu]... zbliżają się

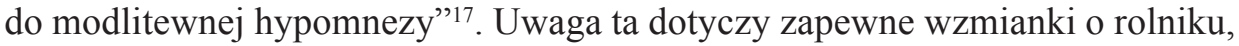
który wielbi bogów grą na fujarce (et satur arenti primum est modulatus avena / carmen, ut ornatos diceret ante deos,... ww. 53-54), oraz chłopca plotącego wianki dla Larów (rure puer verno primum de flore coronam / fecit et antiquis imposuit Laribus..., ww. 59-60).

Hymn kletyczny ku czci bogów agrarnych przechodzi płynnie w kolejną pieśń tego typu, tym razem skierowaną do Amora (ww. 67-82) ${ }^{18}$. W jej ramach prezentuje twórca najpierw okoliczności narodzin, następnie zaś charakter aktywności życiowej psotnego syna Wenery, by wreszcie w końcowej partii hymnu przyzwać boga miłości na świąteczną uroczystość ${ }^{19}$ :

sancte, veni dapibus festis, sed pone sagittas

et procul ardentes hinc, precor, abde faces (II 1, 81-82).

Święty, na ucztę przybądź! Ale odłóż strzały

I trzymaj, błagam, z dala płonące pochodnie.

Zawierająca się w wezwaniu prośba do boga stanowi poniekąd odwrotność apelu, z jakim zwrócił się twórca do Bachusa i Cerery w początkowej partii utworu: o ile tam sprecyzował swoje życzenia odnośnie do strojów-atrybutów boskiej pary na święcie, o tyle tutaj zaklinał Amora o wcześniejsze pozbycie się charakterystycznych oznak, odpowiedzialnych za cierpienia miłosne śmiertelników. Treść błagania eksplikuje a posteriori niezrozumiały w trakcie pierwszej lektury epitet sancte ‘święty', jakim twórca tytułuje boga; określenie

${ }^{14}$ Jak zauważa P. Pöstgens, op. cit., s. 3, za sprawą rogów wyrywał poeta Bachusa z kręgów orgiastycznych i przydawał mu cech wiejskich.

${ }^{15}$ Por. też Hor. carm. saec. 30.

${ }^{16}$ P. Pöstgens, op. cit., s. 16, traktuje ww. 33-36 jako prooimion hymnu.

${ }^{17}$ M. Swoboda, J. Danielewicz, op. cit., s. 66.

${ }^{18}$ Zob. ibidem, s. 66.

${ }^{19} \mathrm{Na}$ Ambarwalia przyzwał Tibullus wcześniej Messalę (ww. 35-36). W apelu do Amora ujawnił się zatem a posteriori niemal boski status protektora poety w utworze. 
harmonizuje z wizerunkiem „rozbrojonego" boga ${ }^{20}$. Ponadto wyraża się w nim troska poety-mistrza ceremonii o pokojowy charakter uroczystości, od początku do końca jej trwania.

Imperatiwus veni 'przybądź', łączący obydwa wezwania na poziomie leksykalnym, nakazuje zwrócić uwagę na jeden jeszcze hymn kletyczny, w którym twórca kieruje swój apel do bóstwa o przybycie przy użyciu tej samej formuły. $\mathrm{Na}$ adresatkę zawierającego się w finalnych wersach elegii I 10 wezwania obiera poeta boginię Pax:

at nobis, Pax alma, veni spicamque teneto,

perfluat et pomis candidus ante sinus (I 10, 67-68).

Ty zaś, Pax dobroczynna, przybądź! Dzierż kłos w dłoni!

Niech wpierw nabrzmieje szata jasna od owoców!

Rzymskiej strażniczce pokoju przydziela poeta rekwizyt, którym w kilku innych elegiach obdarza Cererę - kłosy zbóż ${ }^{21}$, poza tym „doposaża” ją jeszcze o owoce $w$ fałdach szaty. W sposobie prezentacji bogini odzwierciedlają się jej zwyczajowe wyobrażenia z czasów antycznych ${ }^{22}$, wynika on również logicznie z pierwszego członu hymnu (ww. 45-49) ${ }^{23}$, poświęconego zasługom Pax dla rozwoju sztuki agrarnej. Strojna w płody rolne Pax staje się w pieśni Tibullusa zwiastunką urodzaju i harmonii życia wiejskiego ${ }^{24}$.

Jednak za pomocą finalnego wezwania do bogini pokoju poeta chciał uzyskać jeszcze inny efekt. Uwidacznia się on w kontekście sześciu dystychów usytuowanych pomiędzy aretalogią a wezwaniem do Pax. Przynależne do „właściwej” elegii miłosnej wersy 51-66 $6^{25}$ obrazują „bójki Wenery” (Veneris...bella, w. 53) - obraz przemocy wieśniaka wobec żony na skutek upojenia alkoholowego połączony z potępieniem tego czynu przez twórcę (ww. 50-60) oraz erotodydaktyczny miniwykład poety na temat sztuki uwodzenia (ww. 61-66). Za sprawą realizacji hasła militia amori ${ }^{26}$ tworzą one tak wyraźny kontrast $\mathrm{z}$ wiejskim błogostanem, iż hymn, w którym zapewnia sobie poeta nadejście pokoju, zyskuje zabarwienie ironiczne ${ }^{27}$.

${ }^{20}$ Por. H. Geiger, Interpretationen zur Gestalt Amors bei Tibull, Zürich 1978, s. 45. Autor zwraca ponadto uwagę na użycie przez Tibullusa imperatiwu w przemowie do boga, nie wspominając jednak o przyjętej w pieśni konwencji hymnu, co znacznie osłabia siłę jego wywodu - zob. ibidem, s. 45-45.

${ }^{21}$ Zob. el. I 1, 15-16 i el. II 1, 4.

${ }^{22}$ Por. L. Stankiewicz, Ilustrowany stownik mitologii greckiej i rzymskiej, Wrocław 2008, s. v. Pax.

${ }^{23}$ Zob. N. Holzberg, Die römische Liebeselegie. Die Einführung, Darmstadt ${ }^{2}$ 2001, s. 89.

${ }^{24}$ Por. B. Weiden Boyd, »Parva seges satis est«: the landscape of Tibullan Elegy in 1. 1 and 1.10, „Transactions of the American Philological Association” 114, 1984, s. 280.

${ }^{25}$ B. Weiden Boyd, op. cit., s. 89, traktuje je natomiast jako integralną część hymnu na cześć Pax.

${ }^{26} \mathrm{Nt}$. realizacji hasła przez greckich i rzymskich poetów zob. P. Murgatroyd, »Militia amoris« and the Roman Elegists, „Latomus” XXXIV, 1975, s. 59-79.

${ }^{27}$ Zob. ibidem, s. 90. 
Zupełnie pozbawiony cech komicznych jest natomiast hymn kletyczny do Apollina z okolicznościowej pieśni II 5. Twórca rozłamał go na dwie równe części: pierwszym członem (ww. 1-18) zainaugurował, zaś drugim (ww. 105-122) zamknął cały utwór. Za sprawą tego zabiegu hymn uzyskał w heterogenicznym utworze II 5 funkcję ramy kompozycyjnej dla pozostałych gatunków: elegii ajtiologicznej i sielanki.

Wybór Feba na adresata hymnu wytłumaczyć możemy nie tylko powiązaniami tego boga ze sztuką, a zwłaszcza poezją, ale przede wszystkim okazją, dla jakiej powstała cała pieśń. Tibullus napisał ją na cześć starszego syna swojego protektora, Messalinusa, który wstąpił właśnie do kolegium piętnastu kapłanów (quindecimviri sacris faciundis). Kolegium stało na straży Ksiąg sybillińskich - urzędowych przepowiedni rzymskich, zaś te od czasów pryncypatu ${ }^{28}$ przechowywano na Palatynie, w świątyni Apollina jako opiekuna wróżbiarstwa. Z tych właśnie przyczyn twórca skierował swoją uwagę ku bogu słońca.

Pierwszą część hymnu (ww. 1-18 29) rozpoczął poeta prośbą o życzliwość Apollina dla Messalinusa wstępującego w progi świątyni; następnie zaapelował do boga, by ten uświetnił podniosłą chwilę swoją obecnością przy ołtarzach:

Phoebe, fave: novus ingreditur tua templa sacerdos:

huc age cum cithara carminibusque veni.

nunc te vocales impellere pollice chordas,

nunc precor ad laudes flectere verba meas (II 5, 1-4).

Zważ, Febie: nowy kapłan do świątyń twych zmierza.

Tu nuże przybądź z lirą i swymi pieśniami.

Abyś palcami dźwięczne zaczął trącać struny

I abyś w me pochwały swe własne wplótł, proszę.

Apel do Feba o przybycie w sposób tradycyjny realizuje założenia tej części hymnu kletycznego: bóg ma pojawić się strojny w swój atrybut - kitarę ${ }^{30}$, wśród dźwięków pieśni. Tuż za nim zamieścił Tibullus prośbę do Apollina o współtworzenie wraz z poetą artystycznej oprawy uroczystości.

W trzech kolejnych dystychach (ww. 5-10) doprecyzował twórca pożądany wizerunek boga w świątyni, wzbogacając go o wieniec laurowy na skroniach (w. 5) ${ }^{31}$, wytworny strój muzyka ${ }^{32}$ (ww. 7-8) oraz elegancką fryzurę (w. 8) ${ }^{33}$. Zgod-

${ }^{28} \mathrm{~W}$ okresie republiki księgi spoczywały w podziemiach świątyni Jowisza Kapitolińskiego.

${ }^{29}$ Zob. M. Swoboda, J. Danielewicz, op. cit., s. 67; N. Holzberg, op. cit., s. 94. Natomiast M. Swoboda, Albius Tibullus. Poeta elegijny, Poznań 1969, s. 51, za faktyczne rozpoczęcie hymnu uważa dopiero wers 2.

${ }^{30}$ Kitarę jako atrybut Apollina wzmiankuje twórca także w elegii II 3, 12.

${ }^{31}$ M. C. J. Putnam, Tibullus. A Commentary, Univ. of Oklahoma Press, Norman 1973, s. 184, zauważa w tym życzeniu nawiązanie do niedawnego zwycięstwa Oktawiana w bitwie pod Akcjum.

${ }^{32}$ Tak F. Cairns, Tibullus. A Hellenistic Poet at Rome, Cambridge 1979, s. 71.

${ }^{33}$ Rolę włosów Feba jako elementu boskiego wizerunku eksponuje poeta ponadto w pieśni II 3,12 i 23 . 
nie z życzeniem poety Apollo miał się pojawić w pełnej krasie, jak w momencie, gdy wysławiał zwycięstwo Jowisza nad Saturnem (ww. 9-10). Przy okazji deskrypcji Feba wzmiankował twórca obrzędy ofiarne na cześć boga; ten - typowy dla hymnu kletycznego - element pojawiał się również w hymnach orfickich ${ }^{34}$.

Środkowy, laudacyjny człon tej części hymnu (ww. 11-16) posłużył twórcy jako ekspozycja przymiotów inwokowanego boga; ich szczególną wagę zaznaczył za pomocą anafory (tu... tuque..., w. 11 i 13) oraz poprzez wysunięcie zaimka te 'ciebie' na początek 15. wersu. Dobór komponentów aretalogii pozostawał w związku z prośbą zawartą w ostatnich wersach pierwszej partii hymnicznej - o pomyślną straż Messalinusa nad Księgami sybillińskimi oraz obdarzenie go zdolnością wieszczenia (ww. 17-18). Apollo wychwalony został zatem tak ze względu na swe umiejętności wróżbiarskie ( $t u$ procul eventura vides..., w. 11), jak i fakt przekazywania ich augurom (ww. 11-12), haruspikom (ww. 13-14) oraz Sybilli (ww. 15-16). Laudacje boga miały poza tym za zadanie wzmagać uroczysty wydźwięk całej pieśni ${ }^{35}$.

Finalną partię pierwszego członu hymnicznego, o czym już wspominaliśmy, wypełnił poeta prośbą do Feba o życzliwość dla syna Messali; zaanonsował w niej poza tym kolejne zagadnienie elegii - przepowiednie powstania i potęgi Rzymu, wyjawione przez Sybillę Eneaszowi w chwili ucieczki bohatera spod Troi. Płynne przejście z konwencji hymnicznej do narracyjnej opowieści, biorącej swój początek w płonącym Ilionie, było dla twórcy tym prostsze, że Apollo cieszył się mianem założyciela tego miasta ${ }^{36}$.

W finale elegii Tibullus powrócił jednak do konwencji hymnicznej. Wątek erotyczny w poprzedzającej go bezpośrednio sielance stworzył poecie dogodną pozycję do włączenia w obręb drugiego członu hymnu błagania w intencji siebie samego - jako kochanka. Twórca zwrócił się zatem z apelem do Apollina o pozbawienie boga miłości, Kupidyna ${ }^{37}$, elementów jego rynsztunku, przynoszących nieszczęście w uczuciu - łuków oraz strzał (w. 105) ${ }^{38}$. Tym samym sławił twórca Feba jako patrona zakochanych. Przedstawienie Apollina w tej właśnie - nieczęstej - roli nie zostało chyba obliczone na efekt zaskoczenia, już w 3. wersie utworu twórca wyposażył bowiem boga w kitarę, symbol miłości ${ }^{39}$, niejako antycypując późniejszą prośbę.

${ }^{34}$ Zob. M. Swoboda, J. Danielewicz, op. cit., s. 68.

${ }^{35}$ Zob. ibidem, s. 68.

${ }^{36}$ Zdaniem F. Cairnsa, związki boga z Troją mogły sugerować zwłaszcza włosy Apollina zob. F. Cairns, op. cit., s. 71.

${ }^{37} \mathrm{Na}$ temat używania przez poetę imienia Kupidyn w passusach eksponujących nieszczęśliwą miłość zob.: H. Geiger, op. cit., s. 35, p. 1.

${ }^{38} \mathrm{Nt}$. rynsztunku Amora przynoszącego nieszczęście w miłości por. el. II $169 \mathrm{nn}$.

${ }^{39}$ Kitara była atrybutem Erato, jednej z dziewięciu Muz i opiekunki poezji miłosnej. Podobnie jako pozostałe Pierydy, Erato znajdowała się pod opieką Apollina - zob. L. Stankiewicz, op. cit., s. v. Apollo, Erato, kitara. 
Wypowiedziawszy życzenie, Tibullus przeszedł w kolejnych wersach (ww. 107-120) do prezentacji własnych eksperiencji erotycznych; obecność wątku osobistego w uroczystej elegii dla Messalinusa uzasadnił i wytłumaczył brakiem szczęścia w uczuciu. Przy tej okazji zdradził także głębię swojego zaangażowania w poetycką twórczość dla syna Messali: chociaż rozczarowania miłosne nastrajały go optymalnie do kreowania pieśni erotycznych (ww. 108-112), Tibullus błagał sprawczynię swoich niepowodzeń, Nemezis, o łaskawsze traktowanie - tylko stabilizacja psychiczna pozwalała mu bowiem sławić nowego kapłana (ww. 113-120).

Deskrypcję stanów emocjonalnych poety potraktować musimy jako osobny gatunek literacki - ,właściwą" elegię miłosną, włączoną w obręb hym$n u^{40}$. Obok zmiany tematyki przekonuje o tym również zmiana adresata: o ile w partii hymnicznej Tibullus kierował swoje słowa do boga (Phoebe, w. 106), o tyle teraz zwrócił się ku przyczynie nieszczęść, Nemezis (wokatiwus puella, w. 114). Zakończenie elegii miłosnej i powrót w sferę hymniczną sygnalizuje natomiast kolejna apostrofa do boga (Phoebe, w. 121). Finalnej części hymnu (ww. 121-122) nadał poeta charakter modlitewnej hypomnezy: powtórzony apel o spełnienie wyłuszczonych wcześniej próśb poparł własnymi życzeniami dla Apollina - urody dla niego i wiecznej dziewiczości dla jego siostry.

Kwestia koligacji rodzinnych zostaje wprawdzie pominięta w apostrofie do bóstwa z kolejnego hymnu kletycznego (I 7, 23-48), adresat hymnu, uosobiony Nil, otrzymuje w niej jednak familijny epitet pater 'ojciec' z uwagi na życiodajną rolę rzeki ${ }^{41}$ :

Nile pater, quanam possim de dicere causa

Aut quibus in terris occuluisse caput? (I 7, 23-24)

Czy dociec zdołam, ojcze Nilu, z jakich przyczyn

I wśród jakich obszarów chowasz swoje źródło?

Zwrot do Nilu, oprócz konwencjonalnej tytulatury bóstwa, zawiera również pytanie o powody i miejsce ukrycia jego źródeł. Krynice egipskiej rzeki były w starożytności szeroko komentowaną kwestią ${ }^{42}$. Jak trafnie spostrzegają Swoboda i Danielewicz, Tibullus wyeksponował ją na czele hymnu celem ,stworzenia atmosfery tajemniczości wokół egzotycznego adresata"43. Badacze zauważają

${ }^{40} \mathrm{Z}$ podobną sytuacją mieliśmy do czynienia w elegii I 10; wewnątrz hymnu do Pax umieścił poeta elegię miłosną sensu stricto.

${ }^{41} \mathrm{~W}$ czasach antycznych określenie to stosowane było powszechnie w stosunku do boskich opiekunów rzek, por. Liv. II 10, 11.

${ }^{42}$ Zob. m. in. Herodot, II 19; Hor. carm. IV 14, 45 n., Ov. Met. II 254 n., Plin. Nat. V 51 nn.; G. Luck, Die römische Liebeselegie, Heidelberg 1961, s. 88 zauważa jednak w pytaniu Tibullusa zależność od Kallimacha.

${ }^{43}$ M. Swoboda, J. Danielewicz, op. cit., s. 61. Por. też G. Luck, op. cit., s. 89. 
ponadto, że Tibullusowa nieznajomość źródeł Nilu niejako zobligowała go do rezygnacji z podjęcia wątku proweniencji bóstwa, spodziewanego w utworach hymnicznych ${ }^{44}$. Bezpośrednio po apostrofie przeszedł poeta do ekspozycji zasług opiewanego opiekuna Nilu, ogniskując wokół nich centralną część hymnu (ww. 25-48). Aretalogię zainaugurował laudacją zbawiennej dla Egipcjan funkcji rzeki - wylewów (ww. 25-26), następnie przeszedł do zagadnienia kultu otaczającego bóstwo w północnej Afryce (te canit atque suum pubes miratur Osirim barbara Memphiten plangere docta bovem, ww. 27-28) ${ }^{45}$. Przy tej okazji po raz pierwszy wzmiankował twórca identyfikację Nilu z Ozyrysem; jednocześnie zasygnalizował utożsamianie przez „cudzoziemski lud” obydwu bóstw z Apisem, świętym bykiem, w którym - wedle wierzeń staroegipskich - miała mieszkać dusza Ozyrysa. Bogactwo imion adresata w następujący sposób skomentował w artykule Tibullusa wiersz okolicznościowy na cześć Messalli (Tib. I 7) Andrzej Wójcik:

Być może Tibullus nie tylko zamierzał w ten dość oryginalny sposób wyrazić synkretyczne tendencje hellenistycznej religijności, ale pragnął przy tej samej sposobności spełnić wymagania hymnicznego schematu, aby bóstwu sławionemu w hymnie przypomnieć jego wieloimienność $(\pi \circ \lambda v \omega v v \mu i ́ \alpha)^{46}$.

W siedmiu kolejnych dystychach (ww. 29-42) zaakcentował poeta ważką rolę bóstwa (nazywanego tu już Ozyrysem lub Bachusem) dla rozwoju sztuki agrarnej w Egipcie ${ }^{47}$. Następnie (ww. 43-44) przybliżył odbiorcom utworu krąg zainteresowań adresata hymnu, korespondujący z jego pogodnym usposobieniem (non tibi sunt triste curae nec luctus, Osiri, w. 43): taniec, muzykę oraz niosące radość miłostki (levis ... amor, w. 42) ${ }^{48}$. W opis boskich predylekcji wplótł zręcznie deskrypcję Ozyrysa (ww. 45-48). Małżonek Izydy miał opasywać skronie bluszczem, odziewać się w złoto i purpurę oraz objawiać ze skrzynią pełną „,sekretnych przedmiotów” (occultis sacris, w. 48) - związanych z rytuałami ku jego czci.

Tibullus zwieńczył hymn prośbą do Ozyrysa o przybycie (zapewne pod opisaną wyżej postacią) na uroczystość urodzinową (ww. 49-52). Charakter święta objawił się we wspomnieniu Geniusza - opiekuńczego ducha Rzymian,

${ }^{44}$ Ibidem, s. 61.

${ }^{45}$ Jak wykazał. G. Luck, op. cit., s. 89, dwuwers stanowi niemal dosłowny przekład z Kallimacha.

${ }^{46}$ A. Wójcik, Tibullusa wiersz okolicznościowy na cześć Messalli (Tib. I 7), „Symbolae Philologorum Posnaniensium" VIII, 1991, s. 83.

${ }^{47}$ Passus ten zawiera cechy elegii ajtiologicznej. G. Przychocki, W. Strzelecki, Rzymska elegia miłosna (wybór), przeł. A. Świderkówna, oprac. G. Przychocki, W. Strzelecki, Wrocław² 1955, s. 16, klasyfikują tę partię utworu I 7 jako enkomion. Por. też M. Swoboda, op. cit., s. 90.

${ }^{48}$ P. Murgatroyd, op. cit., s. 224, tłumaczy wzmiankę o predylekcji boga do miłostek obszarem panowania Ozyrysa - nad płodnością. Levis ... amor to zarazem jedyny akcent miłosny w okolicznościowej elegii I 7 (por. też el. I 1, 73-74). 
czczonego w rocznice ich narodzin ${ }^{49}$. Poecie tak bardzo zależało na pozyskaniu egipskiego boga jako gościa, że ,wbrew praktyce hymnicznej" ${ }^{50}$ rozbudował hymn o modlitewny człon sankcyjny (ww. 53-54), obiecując w nim Ozyrysowi wota - kadzidlany dym i placek $\mathrm{z}$ attyckim miodem ${ }^{51}$. Jaki solenizant skłonił jednak twórcę do tak wielkiego zaangażowania w przygotowanie urodzin? Dla kogo pragnął pozyskać Tibullus najważniejsze bóstwo egipskiego panteonu? I dlaczego właściwie egipskiego? Na te pytania odpowiedź może przynieść jedynie potraktowanie hymnu jako elementu służebnego wobec innego gatunku literackiego, któremu udzielił twórca prymatu w heterogenicznej pieśni I 7.

Obecność modlitwy i hymnu w korpusie elegii miłosnych Tibullusa interpretować możemy na wiele różnych sposobów. W pierwszej kolejności dowodzi ona - kwestionowanej zwłaszcza w starszej literaturze przedmiotu - doskonałej orientacji poety w poezji greckiej oraz umiejętności twórczego przenoszenia zawartych w niej schematów kompozycyjnych w świat poetyki augustowskiej. Nośna informacyjnie wydaje się poza tym tożsamość adresatów obydwu form sakralnych; za jej sprawą przypieczętowuje Tibullus swój status religijnego Rzymianina par excellence - przywiązanego nie tylko do bogów miłości, ale także rolnictwa, pokoju oraz sztuki. Rozpiętość uwagi poety pomiędzy przyporządkowane owym bogom rozmaite sfery życia ludzkiego eksponuje wreszcie zawartość treściowa segmentów modlitewnych i hymnicznych; wyłania się z niej dbałość elegika o zachowanie ładu i harmonii zarówno na obszarze relacji międzyludzkich (związek miłosny z Nemezis, przyjaźń z Messalą), jak i w umiłowanej przez niego scenerii wiejskiej.

\section{LA PALETTE DES GENRES LITTÉRAIRES CHEZ TIBULLE. HYMNES RELIGIEUX ET PRIÈRES EN TANT QUE PORTEURS DU PROGRAMME POÉTIQUE DU POÈTE ÉLÉGIAQUE}

\section{Rés u mé}

Dans ses élégies amoureuses, Tibulle se sert souvent d'hymnes religieux et de prières, surtout afin d'exprimer aux dieux son besoin de réciprocité dans l'affection. Par ailleurs, ces genres lui permettent de souligner dans ses poèmes l'importance de la vie rurale et de l'amitié avec Messala. Grâce aux hymnes et prières qui sont d'origine grecque, Tibulle démontre aussi sa connaissance profonde de la poésie hellénique.

\footnotetext{
${ }^{49}$ Zob. L. Stankiewicz, op. cit., s. v. geniusz.

${ }^{50}$ M. Swoboda, J. Danielewicz, op. cit., s. 62.

${ }^{51} \mathrm{~W}$ zamyśle poety na uroczystości miały przenikać się pierwiastki rzymskie, greckie i egipskie - por. G. Luck, op. cit., s. 91.
} 